\title{
Sino-Africa relations: Gradual changes in Chinese foreign strategy towards African countries
}

\author{
Sahibzada Muhammad Usman*1-2 | Zekun Lyu ${ }^{3}$
}

1. Department of Political Science, Faculty of Social Sciences, University of Pisa, Italy.

2. Department of Political Science, Abdul Wali Khan University, Mardan, Pakistan.

3. Department of Political and International Sciences, University of Siena, Italy.

Correspondence Emails: s.usman@ @ studenti.unipi.it | usmangull36@ gmail.com

\begin{abstract}
China is one of the world's foremost economic powers, affecting many countries' economies and political issues. China standing by the five principles of peaceful coexistence, is ready to cultivate friendly cooperation and ties with all countries that contribute to international peace, security, and mutual prosperity. Africa is an important factor for global stability and prosperity with the highest number of developing countries. Africa is still of considerable significance to the Chinese Government. Therefore, the Chinese government wishes to present China's African strategy and its action to implement them and its plans for cooperation in different areas to facilitate the steady development of China-Africa ties in the long period. However, China's foreign policies are changing and developing recently. This study utilized qualitative analysis to identify the collaboration and relations between African countries and China to know how Chinese foreign strategy changes Africa's strategic ramifications and repercussions. The findings showed that the partnership between China and Africa by win-win strategy, from moral emphasis throughout the colonial phase to tactical considerations and non-intervention to constructive involvement on the continent, are three strands of foreign strategy shifts.
\end{abstract}

\section{Article History}

Received:

December 20, 2020

Last Revised:

March 20, 2021

Accepted:

April 9, 2021

Published:

May 6, 2021

Keywords: China, Africa, foreign strategy, foreign policy, win-win strategy, ideological collaboration, economic cooperation, foreign affairs.

How to Cite: Usman, S. M. \& Lyu, Z. (2021). Sino-Africa relations: Gradual changes in Chinese foreign strategy towards African countries. Liberal Arts and Social Sciences International Journal (LASSIJ), 5(1), 154-167. https://doi.org/10.47264/idea.lassij/5.1.11

Publisher's Note: IDEA PUBLISHERS (IDEA Journals Group) stands neutral with regard to the jurisdictional claims in the published maps and the institutional affiliations.

Copyright: ( 2021 The Author(s), published by IDEA PUBLISHERS (IDEA Journals Group). This is an Open Access article published under the Creative Commons Attribution-NonCommercial 4.0 International License (http://creativecommons.org/licenses/by-nc/4.0/) 


\section{Introduction}

China has a greater international impact on foreign strategy than domestic considerations. Therefore, Chinese foreign strategies cover several concerns in different fields in many countries, especially developing countries. China's strategy is building the relationship with the other countries both in support and investment, even in political issues. African countries have good cooperation with China for a long back, and these countries might undergo the Chinese foreign strategy. This study revealed that China has managed to draw and pursue cooperation from most African countries by executing peaceful growth and its policy of instituting strategies. Regardless of the existing political and economic relations between Africa and China, this research implies that subtle shifts in China's foreign strategy towards Africa have various political and economic consequences, ranging from the single-aid scenario to a win-win situation, non-interference to constructive participation.

After the early Cold War, China has had Africa at the heart of its foreign policy. This attention has increased over the past two decades, with Beijing expanding its diplomatic, technical, security, and economic commitment substantially with almost all African countries. China's deeper links with Africa have helped the continent in several key ways, particularly through addressing the serious infrastructure deficiency of many African countries. Beijing has also continued to build on its universal continental footprint to support an alternative democratic paradigm promoting state-led unliberal government for internal interference on the mainland and the ever - domination of Beijing in Africa. It also assesses African media exposure through Beijing and invites African allies to promote their foreign interests. In Africa, China has other key economic and strategic interests, particularly in the procurement of resources. Still, this study focuses solely on the collaboration and relations of China and African countries in economics and politics. The research reviews and its evaluation contribute to the Chinese African relationship debate, particularly the need to regularly assess political and trade partners. It shows how a shift in a country's trade partner's external policy will influence their country's economic and political activities. This study was conducted to identify the effects of the Chinese Foreign strategy on Africa. It aims to examine the strategic ramifications and repercussions for Africa if the Chinese foreign strategy changes.

\section{Literature overview}

In contrast to China's periphery and the main powers, Africa is a region with much smoother ties and diplomatic success with China. African nations do not present China's national security with direct threats or obstacles. There is no territorial dispute between Africa and China due to the geographical gap. The pursuit of democracy in Africa-China has little, if any, ideological significance. While there is rarely disagreement, differences are often less stressful or controversial than Chinese meetings with their neighbours and other major forces (Niall, 2019). As China already has reasonably constructive and stable relations with Africa since long back, Africa's support for international and domestic political agendas in China is significant. In recent decades, China's deepening interaction with African nations has been widely received by scholars. Scientists have thoroughly explored the impacts, motivations, and nature of this relationship. In the sense of an increasingly globalized environment, Alao (2014) wrote extensively about China's participation in the African continent. Africa has undergone an explosion of public and private Chinese firms and both nations have cooperated over the last two decades. These businesses have formed a wide catchment area ranging from primary mines to secondary services. The high import levels of China from African region suggest that more 
access is urgently required to African markets, particularly to African mineral assets, such as energy assets, which are crucial for driving its complex industrial and economic growth. Minerals about which China is responsible, but not limited to bauxite, copper, cobalt, plum, phosphate, iron, gold, plutonium, and oil. For Bijian (2005), China's growth policy moved from inefficient energy usage to a modern technical and economic performance direction to resource use. The growing trade figures, the numbers of governments' mutual treaties, development assistance, and the Chinese people working in Africa clearly illustrate this renewed emphasis on Africa after 2000. These relations are prompted by a shared philosophy of counter-western expansion during the colonial period and now the developing world's economic growth requirement. Western countries perceive China's position in Africa as a challenge to the continent's political and economic aspirations.

China sees Africa as a continent that is peculiar to its paradigm of economic governance and growth. In recent years, the export of these ideas to African countries has been increasingly confident. The recent rise of China to superpower status and its continued penetration into the worldwide economy has significantly affected many nations' economies and political situation, particularly the developing nations. China establishes its position on developing countries through its foreign strategy. The building and strengthening of friendly ties and cooperation with developing countries, particularly African countries, often played an important role in China's independent foreign policy of stability (Ahmad, 2019). During his African tour of 1960, late Prime Minister Zhou Enlai applied the rules regulating African countries and China's relationship. Africa's main position was reaffirmed by successive Chinese leaders within China's wider external strategy dates from the beginning of the Cold War. The commitment of China has spread to the continent in recent years. In particular, the African countries are one of the most countries involved in the Chinese foreign strategy. Africa would have significantly benefited from China's right foreign approach and supportive development assistance at minimal costs and under no condition attached. This deepening relationship is at the price and the western investment moment in the region. Since then, criticism and hate have arisen against China's interests and its new position in Africa. However, cooperation between Africa and China has been formed since dated back to the colonial period. During this time, cooperation between China and Africa was motivated by ideology, particularly China's anti-imperialist and anti-Soviet expansionism.

According to Anshan (2007), contemporary Africa-China relations have witnessed a transitional change from an intellectual focus towards social but primarily political and economic diversification. More precisely, associations have changed from the philosophy of colonial and Soviet expansionism to the discovery of natural resources. Other than social and political considerations, economic collaboration forms the base of China's foreign strategy towards Africa. While China's role in Africa is primarily motivated by economic interests, political concerns cannot be overlooked. There should be no doubting the extent of trade and China's penetration in Africa today. Africa-China has improved relations in social, political, and economic realms, where China has acquired access to natural resources and political power, and Africa gets development aid (Duarte, 2012; Khatoon et al., 2018). China has changed to being a large- scale importer from becoming an overall exporter of raw materials and minerals and turned to Africa as a possible response to the increased demand for oil. China recognizes improvements in policies that can influence or have political and economic consequences in other countries; continuous monitoring and assessment are important. The African State's problem lies in the growth of China's strategy from its conventional failure to intervene with other countries' internal politics to more conflictual policies. Regardless of the 
existing political and economic relations between Africa and China. This research implies that subtle shifts in China's foreign strategy towards Africa have various political and economic consequences, ranging from the single-aid scenario to a win-win situation, non-interference to constructive participation.

\section{Research methodology}

In this study, a qualitative analysis has been used to investigate the nature of relations between the African continent and China; and demonstrate how the Chinese policies affect the African countries. Using the data collected from the previous research, investigations, interpretation of dynamic social phenomena directly. Data was collected from different sources: journal publications, books, online articles, and official diplomatic communication reports on the Chinese websites. During the writing, tools of empirical understanding such as analytics and information processing synthesis have been utilized. The paper focused on foreign strategy and economic categories which China towards African countries. China's cooperation and partnerships with African countries have been overlooked as a critical component of Chinese foreign strategy to this continent.

\section{Chinese foreign strategy towards Africa: a discussion}

\subsection{The Changing foreign policy of China}

Recently, the Chinese foreign strategy has been perceived as more assertive as compared to its policies of $20^{\text {th }}$ Century. The appraisal in this article is focused largely on both the language and behaviour in foreign strategy. While China recently seems not to have dramatically increased its army expenditures, the terror of greater boldness has reawakened China's view of itself as a destabilizing or disruptive power in the $21^{\text {st }}$ Century (Perlo-Freeman, 2014). In China's foreign strategy dialogue, the terminology and substance of the first-ever Military Strategy White Paper published in 2015 is perhaps the best example of Chinese affiliation. The Military Strategy defines China as a force in its near neighbourhood, under multiple conventional and non-traditional - and challenges worldwide. If there is a clear reference to the challenges of 'hegemonism, politics of power and neo- interventionism,' China implicitly shows its concern with America's rebalancing policy, especially in Asia (Johnson, 2015). In this sense, China is willing to create the military and strategic capacity required to protect its development interests, territorial integrity, and national unification. Beyond propaganda and its successful involvement in the war against piracy in the Horn, China displayed its willingness to project its militarized capability far beyond its frontiers. China also has been strongly committed to advocating its sovereignty in the South and East Seas of China and has opened up nationalistic voices to back its rights.

Along with this, China has begun to challenge global governance's major frameworks by calling for local reforms or developing alternate organizations. China is gradually positioning its foreign strategy as an alternative to existing values-based global affairs. Therefore, it highlights autonomy and non-intervention as the basic principles for foreign relations. Some of the scholars criticize the authenticity of the affirmation that China has made no unilateral and exclusive turn towards assertiveness of its foreign strategy for the continued presence of important American influence in East Asia (Jerdén, 2014). China's foreign strategy's assertiveness is an alternative to be understood in the wider sense of its external affairs. This background is identified as one of ambiguity. Indeed, the true effect of China's foreign rise and 
the utilization of China's influence and strength are still unclear (Burnay \& Maïra, 2013). The interdependence of numerous domestic and foreign influences and the lack of a new Chinese policy clarify this confusion (Christopher, 2020).

Chinese foreign strategy and external links remain unclear as they rely on China's ability to overcome its key local problems, such as entrenched corruption, environmental degradation, ethnic separatism, export dependence, and income disparities. In this regard, the future of foreign strategy and international Power is primarily based on the Communist Party's ability to preserve China's way of change, as Zhang Zemin and Xi Jinping stated. It involves economic prosperity, political, social harmony, and territorial unity. The argument that 'Chinese foreign strategy is a result of domestic and international influences' remains especially right today (Tarun \& Ryan, 2019). The internal fact and limitations inform China's leadership's foreign strategy decisions, whose authority is largely decided by the CCP's success, to convince people to qualify as leaders in transforming the country and improving people's welfare. Besides, the lack of a "big strategy," which will inform Chinese foreign strategy in all thematic and regional regions, also concerns instability (Jisi, 2011). China's foreign policy consists mainly of realistic judgments focused on a mixture of geopolitical and domestic considerations describing (Shambaugh, 2014) Chinese foreign strategy that is often inconsistent (Zhao, 2014). More precisely, China's foreign strategy tends to cause four dilemmas:

Firstly, the finding of a balance between greater reliability and the strengthening of Chinese soft power. A willingness to increase its international position and control over global governance and respond to the growing nationalism of particularly younger generations encourages greater assertiveness. In exchange, China still thinks that its soft Power needs to be strengthened and its foreign profile formed against global public opinion's backdrop. The core principles that direct China's foreign strategy - "Peaceful Development - which is China's constructive contribution to global peace - and the discourse of "non-interference" illustrate the difficulty of this challenge and China's need to strike a balance between the protection of its national interest and the conciliation of its near and distant neighbours.

Secondly, the quest for a balance between circumventing or supporting the multinational institutions and the current structures of global governance. In the sense of the Western powers creating the bulk of established institutions and systems after the Second World War, China had to select between participating, changing, or circumventing the current international system of governance. The quest for greater power is an important element in China's international governance approach, whether by pushing or circumventing an overhaul of the established institutions.

Thirdly, China faces the dilemma of managing its foreign policy issues through multilateral platforms because it is deeply interdependent with the world. This ultimate problem is also related to China's non- or just partial acceptance of global law and global legal structures such as the International Criminal Court and the WTO Conflict Resolution Process.

Finally, as for the real scope of its position as a global and regional entity, China faces a dilemma. The United States' general relationship is clearly of prime significance since China remains the leading regional and global competitor. Chinas' potential to become a global or regional force depends on its political and capacity to expand its reach and direct impact outside its surroundings, for instance, in Latin American and African. 


\subsection{Chinese foreign policy towards Africa}

In Beijing's global policy, Chinese observers have questioned Africa's low priority. They call for a new interpretation of the complexities of China's foreign strategy among the major powers, the periphery, and developing nations and for China to look at and reflect on Africa from a more strategic point of view. However, Africa is a "long-period and strategic problem, as China will still depend on Africa for funding, while "time" and "ephemeral" are the "priorities" of China's foreign strategy. Despite Africa's low priority in China's general global geopolitical mapping, still, China-Africa's contribution attracts excessive global interest, scrutiny, and publicity. Many causes cause this disparity. First of all, in China's "prestige diplomacy," Chinese leaders have actively highlighted Africa in their foreign-visit agendas (Gill \& Reilly, 2007). During their administration, former President Hu Jintao made a series of multinational visits to Africa. In 2013, Africa was the focus of President Xi Jinping's first overseas visit (Anshan, 2007). Prestige diplomacy has allowed China to join the once "forgotten continent" to foster policy relations and extend trade cooperation. In China's pursuit of democracy in global relations' and a new global order, consolidated friendships with Africa have also strengthened China's developing country's solidarity and identity with the developing world (Sun, 2013). Secondly, the Chinese priority is not the African region, and economic links with the continent are a small percentage of Chinese people.

In 2009, China became Africa's largest trade partner, and African governments give Chinese foreign investment a high priority. Moreover, Chinese investment and loans are daunting and intimidating in terms of Africans. When the Chinese Development Bank (CDB) provides \$3 billion loans in 2012, Ghana observers noted that the sum amounted to almost $10 \%$ of Ghana's GDP per annum (Xinhua News Agency, 2012). However, the scale of these ventures and their opaque nature may not be viewed as daunting by Chinese bankers and officials (Brautigam, 2009). This opaque nature, but not least, attracts foreign interest and criticism because of China's economic operation in Africa. Chinese investments have been chastised in lessdeveloped nations, authoritarian or semi-authoritarian nations. Popular critiques include the following: China's economic commitments only apply to natural assets; it encourages the use of authoritarian governments; it inhibits attempts to reinforce human rights and democracy; and it leads to social, corruption and environmental destruction, etc. Critiques have generated more concern and noise in China's new company in Africa and the potentially detrimental consequences. During interviews, Chinese policy observers and officials expressed unhappiness with the "fair scrutiny and partial criticism" of Chinese initiatives in Africa by international media. Nevertheless, they understand that China is increasingly being exposed in the future to this "unfair treatment, considering its undemocratic political structure and the popularity of some Chinese ventures and companies (Sun, 2013).

\subsection{Areas of cooperation between China and Africa: Win-win strategy}

After China's African policies have been changed, the focus is on cooperation, and a win- win trend, accompanied by the shift in China's assistance patterns, the unitary aid offered in many forms free of charge, for example, as government inference of interest loans at a favourable amount, co-investment funding combined and gratuitous aid. Chinese-African politics inevitably have their geopolitical target, but one of the points is to help African nations get out of poverty and consolidate freedom. The practice of partnership between China and Africa strongly shows this fundamental norm (Deych, 2018). The transition of cooperation between China and Africa takes assistance, sharing growth expertise, and the win-win economic interest 
trend. African nations indicated that increasing foreign investment through the growth of productivity is more successful than conventional assistance. China's free help had a tremendous return from African allies: their African friends took China to the United Nations. The irony is that help for free cannot alter the truth of poverty. In 1982, Hu Yaobang observed, as regards financial support, the present method is disadvantageous to both sides, refereeing from historical experience. China, therefore, began exploring the reform of foreign aid and trade. The foreign exchange reform started in 1987, and then China began seeking other forms of foreign assistance. In 1987, Aniye Sugar Plant was poorly operated with Chinese assistance due to a lack of managerial and technical expertise. After negotiating a deal, the management was taken over by Chinese experts and successfully executed. There was a large improvement in business benefit, which the government of Togo celebrated.

This activity was being applied to other Chinese-assisted companies as a mix of international assistance and the mutual venture collaboration that started to be evaluated in 1992. In Mali, the same thing happened in 1991. The Mali government announced that the Segu Textile Plant would be privatized vis-à-vis the Chinese government's aid initiative. After talks, the Mali's government agreed to pass $80 \%$ of shares to China's companies, subject to seventeen firms responsible for paying the loan. Mali and the Chinese governments were to grant this joint venture company favourable conditions. The company has since run smoothly, with a value of CHF 7.6 billion in 1996. China's projects have articulated China's interests to the weak community, including the aged, women, and children. After many years of experiment, interest loans were deducted by the Government on profitable terms and were introduced in 1995. During the year, Vice Prime Minister Li visited 13 African nations to clarify China's latest foreign assistance policy. One year back, China concluded beneficial loan arrangement deals with 16 African nations. African countries eventually approved the modern method of assistance. A new process of bilateral friendly relations was launched in 2000 by the ChinaAfrican Cooperation Forum. China followed out its promises of debt relief in follow-up actions, helping African human capital growth, and promoting Chinese businesses to invest in Africa. As a result, free unitary aid has increasingly shifted to various types whereby interest loans have been deducted on profitable terms, global assistance with the partnership, mutual investment, and gratis aid.

Economic interest and bilateralism as China trades with African nations typically considers African nations' needs to create a win-win situation. China announced an exemption from the duties to export goods to China from 25 least-developed nations in Africa. According to estimates by the Chinese custom services, in the 2005 period, the volume of 19 zero-tariff products was 340 million dollars, $60 \%$ higher than that of Chinese manufactured goods from Africa at the same time. It suggests a positive position for the policy in supporting African exports to China and developing trade between Africa and China in general. Approximately 12 thousand African trade leaders attended the $97^{\text {th }}$ Guangzhou Trade Fair in 2005, and the market value hit $\$ 1.7$ billion. The level of business with China crossed over 100 million in African nations in 2005. In 2000, trade between Africa and China had two major characteristics. One is that Chinese imports from Africa increased their export to Africa and that African trade with China has been strengthening. In 2005, trade continued to grow, totalling $\$ 39.74$ billion (China Statistics Press, 2005). For the third time in the last five years, imports were higher than exports. As trade grew, the export items' elements became best suited to Africa, and the level was increased. High-tech computers, electronics, and products expanded exponentially, accounting for over half of China's exports. 
Since China stresses on the mix of technical assistance and economic support, this structure will undoubtedly benefit African technical growth and an exchange stage in learning progress and evolving strategies. No doubt, this is a win-win scenario for both sides. Africa's condition shows both challenges and China's harmonious win-win policy ideology in the sense of globalization. China's participation in Africa is met with five challenges: contradictions among the interests of African and China firms, contradictions between China's national interests and the interests of Chinese companies, the tension between China's interests and the interests of the main nations, and contradictions between China's need for natural resources. There are ways to solve these issues: to recognize partners' needs to maintain a cooperative mutual effort, integrate China's and other interests to guarantee equality of cooperation, align short-period interests and long-period interests to guarantee the cooperation's vitality to improve selfdevelopment potential for partners. This method can be called impractical or desirable, but people must work together to solve problems. Challenges and wars proved to be selfdestruction. China can only be a fair and responsible nation by having a good and applicable path (Anshan, 2007).

\subsection{Ideological collaboration for realistic reasons}

In the 1980s, China's relations with Africa have been strongly driven by intellectual debates aimed primarily at scaling back American imperialism, European colonialism, and Soviet expansionism. Zhou Enlai's African tour affirmed China's interest in supporting African political parties and declaring Africa an intellectual battlefield against Russia and America (Mohan \& Power, 2008). The CCP (China Communist Party) supported and funded militant African independence groups with rhetorical military and financial preparation and resources after those commitments (Shinn \& Eisenman, 2012). According to Anshan, the 1982 CCP Party Conference had adopted a new policy for including other radical political parties in the 1960s. The CCP had declined to partner with non-communist political parties in Africa. The policy included equal, independent, and non-interference in internal matters, concepts inspired by pacific coexistence principles in 1954. Mohan \& Power (2008) agreed with Anshan that Mao and Enlai's era concentrated on politics and ideology in defining the values regulating cooperation and assistance to developing nations (see, Mukhtar et al., 2020). China's philosophy cocooned the ideas of democracy and nationalism that strengthen China's reputation in Africa while demonizing the West and its colonial and imperialist dominance philosophies. These positive changes in how African nations interact with the CCP have no longer been motivated by ideology.

This divergence from orthodoxy reconfigures China's relations with Africa, of which three meanings can be drawn. Collaboration with Africa's governments is no longer based on socialist ideology but encompasses all groups, irrespective of their ideological positions. A corporation with Africa is no longer political but includes engagement between sub-national players such as ministries of commerce, NGOs, foreign relations, multinational cooperation, and provinces. At the core, China's foreign strategies have changed from the "Cold War" paradigm to a more realistic and classical pursuit of monetary self-interest in the form of raw materials and the building of influence through military assistance, trade, and investment. The transition from ideological focus has also shifted China's policy of cooperation with its African nations. It changed its strategies steadily from war to collaboration, from revolution to trade growth, and from alienation to global participation (Otele, 2020). In 2007, Anshan acknowledged China's strong ties with its philosophy. In reality, for Wang, China's philosophy is the reference and pillar of China's relationship with other nations. The research now assumes 
that this connection between China's foreign strategy and ideology is a flaw since ideology is likely to expand. The study claims that as philosophy emerges in foreign strategy as a driving principle, it would follow suit. Consequently, the interaction between these two variables is one of the most significant and important instances in which China has moved from how it usually communicates with and affects African countries.

\subsection{Switching the policy of non-interference to constructive intervention}

China's claim for non-interference policy and the developing ties between China and Africa has been the subject of most modern discussions. China consistently justified its nonintervention policy by claiming that it is a breach of individual states' sovereign rights that mix human rights and independence with economic partnerships (Tania, 2019). In 2004, in response to the Sudan crisis, the China's Deputy Foreign Minister affirmed the Chinese stand on this issue. Consequently, China cannot interfere in Sudan's internal structures; he says China does not combine politics with business. For example, China vetoed UN Security Council Resolution 1564 in 2004 to enforce Khartoum's restrictions to avoid the mass massacres of innocent civilians. China's business here relates to where its economic and political priorities lay. China is involved in Sudanese oil and will not risk its market politics. The same refers to the partnership between Zimbabwe and China (Osondu, 2013; Rahim et al., 2019). Strict commitment, except in the event of foreign mockery, to non-interference, does not mean that China is so noble in its philosophy or the coexistence values that govern its international actions. A considerable international strain was recently put on the ideals of coexistence containing the disputed role of non-interference accepted by China with African nations. As Meidan (2006) says, the tensions come primarily from Western countries that have become impatient and irritated at China's free-riding tendencies. Thus, there have been diplomatic cracks or signs of Chinese policy changes. The increasing inclusion and role of China in the international community have necessitated this. Given China's prior unwillingness to press Khartoum, it has been a significant participant in truce talks and the deployment of security forces in Africa's conflict zones. In contrast to any other UN Security Council participant, China has greatest number of peacekeepers working in UN missions (Tjønneland, 2014).

China has largely been cautious in implementing the concept of non-interference. The theory of conformity is affected by domestic concern. For example, in the face of a likely boycott of the 2008 Olympics, China went from non-interference to constructive participation. Beijing thought that this was a historical event to export its community and identity. China also mediated a peacekeeping force between African Union and the UN through an arrangement in Ethiopia. To that end, China told President Al-Bashir that debt would be cancelled, and a chalet would be constructed. It is prioritizing Chinese foreign policy preferences ranked over ideological goals. Notwithstanding various and ongoing critiques of its non-interference attitude, China agreed to only heed the global uproar in Sudan when it comfortable to have, i.e., if the political environment was modified with greater priority than economic interest (Osondu, 2013; Khan et al., 2020). Several problems are confronting China's expanding business ambitions on the continent. Such threats come from policy problems, insurgency, graft, Chinese employees and people safety, reputational risks, and various other weaknesses to political risks. Terrorism highlights Africa's future problems and challenges China's economic and political opportunities on the continent. In turn, it pressures China to represent foreign policies in these risky environments and allow them to continue to operate (Tjønneland, 2014). Beijing first reacted timely and progressively to foreign pressures (Alden \& Large, 2013). After the outbreak in Sudan in 2013, Chinese officials Riek Macha and Salva Kiir 
actively negotiated a cease-fire accord. China's first time has arisen from its illustrious and flawless worldwide structure to solve concrete problems of global concern.

\subsection{Focus of foreign strategy on multiple channels}

The Chinese African strategy of transition from the focus on diplomatic communication to the multi-channel trade at various levels. Till 1978, China's African policy was based on three dimensions: a) it supporting Africa's people in the fight against imperialism, colonialism, and domination; b) it also supported the African nations in the economy's growth; and c) in politics, China supported the autonomous African movement (Weinstein \& Henriksen, 1980). Apart from its spiritual encouragement, it also rendered military aid, such as recruiting political and military workers (Ottaway, 1978). Ever since its independence, China began pursuing Africa as an ally in its struggle against hegemonism and imperialism. Concerning economic aspect, China's support to the African nations took place under tremendous economic pressure from within due to morality and philosophy's actions to fight with superpowers and foster the happiness of the marginalized peoples worldwide. The international cooperation between Africa and China involved mutual exchange and economic assistance. In 1977, the gross mutual trade amounted to $\$ 720$ million. For the period, China-funded 36 African nations with $\$ 2,476$ billion for external assistance, representing roughly 58 percent of China's overall international aid (Weinstein \& Henriksen, 1980). While the Soviet Union was the main arms dealer in Africa, its monetary assistance to Africa was way behind China. The 1990s were a consolidation era. The Chinese Government often invites diplomats from developing nations to China to hold a symposium or share ideas and growth experiences to make African diplomats know China better. It eventually became a window for diplomats to grasp China's history and present. The host, the University of Chinese Foreign Relations, continuously organized the symposium for nine years, with participants from nine international organizations and more than 130 nations. One hundred sixty-one young African diplomats engaged in nine symposia from all the African nations with diplomatic associations with China and ten African international organizations (Adaora, 2020).

The symposium contains the first component classes on Chinese arts, culture, history, etc., followed by a trip of twelve poor and rich regions. To date, relations between China and Africa have grown at all levels. China has signed a mutual investment promotion and security pact with 26 African nations, and cultural and trade deals with more than 40 African nations. The multilateral cooperation structure between China and Africa is increasingly evolving, and ways of cooperation are multifactorial. China also has a diplomatic advisory scheme with the ministries of foreign affairs of 28 African nations. The exchange covers different areas, including military fields, civil material, medicine, sanitation, culture, education, industry, and economics. The most rapid growth in educational exchange and international collaboration. Africa-China exchanges took on numerous types and in different fields, including primary visits on both sides of the country; students who trained on the other side with a focus on graduates; teachers of China in different African nations, staff training, and the development of different laboratories in the states of Africa. In 2005, eleven universities, including highlevel education administration, long-distance training, and vocational-technical training, with 12 seminars and training (Sandra, 2001 \& 1999). The participants come from 41 nations, mainly the African countries, including technicians, educators, and government officials. In Peking, State Councillor Chen made four pledges on collaboration and trade, educational assistance and organized a first Education Forum. Together with the Minister of Commerce and the Department of International Affairs, the Ministry of Education conducted the seminar 
on sharing educational staff experience from developed nations. About 70 participants from numerous universities shared ideas and perspectives. The first China-African University Forum took place at Zhejiang Normal University, which cantered on capacity building in developed nations for higher learning institutions, restructuring management in education institutions, and international collaboration.

\subsection{China-Africa commercial and economic cooperation}

There are also new characteristics in the area of economic cooperation. The first is state- owned firms, private companies, and three sponsored companies in the African market. Private businesses are expanding quickly, and they tend to keep up with state-owned corporations. Secondly, trading commodities indicate that China and Africa are very complimentary (Ministry of Commerce, China, 2005). Thirdly, economic collaboration is not about trade, with quick growth being shown in other fields such as consultancy, labour, contracts, and finance. Chinese companies spent $\$ 1.25$ billion in Africa, including agriculture, shipping, natural resources, commerce, industry, and others. Chinese contract-building ventures are rising dramatically. Fourthly, the Government has sought to provide numerous business opportunity services in Africa, such as establishing eleven investment and enterprise promotion centres, the regularization with African nations of mutual trade and economic commissions, the timely declaration of business prospects and trading guidelines, and related information in Africa. In brief, five changes have been made regarding economic collaboration. Unitary state-run trade has shifted to private and public business. The unitary form has expanded dramatically to several ways of cooperation at multi-level, trade value, and the Chinese balance of African surplus, helping for win-win cooperation. It was noted that the days when cooperation between Africa and China was mainly focused on cooperation between states, international political support, and economic aid (Mahamat, 2006).

\section{Conclusion}

This paper reveals the complex existence of China's foreign strategy and African governments' difficulties in doing business with the world. The concept of non-intervention in other countries' affairs is a particular feature of Chinese culture and a core component of China's foreign strategy that has caused such uncertainty. Other essential aspects of China's foreign strategy include its willingness to identify with the nations with which it is committed. The debate described three occasions where China's foreign strategy has shifted or a strong chance of reform. The first is the way that China used to distribute assistance in Africa. China granted assistance most of the time to African nations. Support was given on a humanitarian basis, and nothing was requested in exchange. However, as its economy has grown and its influence on the continent has expanded, China now offers conditional funding to improve access to political and commercial spaces in Africa. Secondly, the concept of non-interference in China's foreign strategy is another way of recognizing transition. As a philosophy, it is expected to grow in the international community with changing circumstances. In this case, the constructivist principle of socialization affects the pace at which transition takes place. China has been globally blamed for neglecting human rights problems in areas where it works. Finally, in China's strategy on Africa, a change from ideological to tactical considerations is clear. Cooperation was once focused on anti-Soviet expansion and brotherly assistance during the colonial period but is now primarily commercial. The most notable aspect impacting China's market and political circumstances is Africa's turbulent political climate. As the growing player in the extractive market, China faces major political risks in these nations. These threats include disruption to 
facilities, expropriations, policy inconsistencies in Chinese national's abduction, and other instability. The Chinese are more likely to interfere with securing their residents and investments in Africa. Altogether, these findings illustrated that the whole picture of China's foreign strategy in Africa. Also, showing the changes in its strategy would affect African countries in both economic and political issues.

\section{References}

Adaora, O. (2020). Testing an 'all-weather friendship': China and Africa after COVID. ISPI Italian Institute for International Political Studies. https://www.ispionline.it/en/pubblicazione/testing-all-weather-friendship-china-andafrica-after-covid-26946

Ahmad, S., Gull, A., \& Irfan, S. (2019). Sino-African relations: Economic opportunities and challenges for China. Liberal Arts and Social Sciences International Journal (LASSIJ), 3(1), 61-72. https://doi.org/10.47264/idea.lassij/3.1.6

Alao, A. (2014). China and Zimbabwe: The context and contents of a complex relationship. SAIIA Occasional Paper, 1-28. https://media.africaportal.org/documents/saia_sop_202_alao_21041017.pdf

Alden, C., \& Large, D. (2013). China's evolving policy towards peace and security in Africa: Constructing a new paradigm for peace building? China-Africa Relations: Governance, Peace and Security. https://media.africaportal.org/documents/China_Africa_book_3.pdf\#page=26

Anshan, L. (2007). China and Africa: Policy and challenges. China Security, 3(3), 69-93. https://cpfd.cnki.com.cn/Article/CPFDTOTAL-BDFZ201305003010.htm

Bijian, Z. (2005). China's peaceful rise to great power status. Foreign Affairs, 84(5), 18-24. https://doi.org/10.2307/20031702

Brautigam, D. (2009). Rogue donor? Myths and realities in the dragon's gift: The real story of China in Africa. Oxford University.

Burnay, M., \& Maira, M. (2013). Introduction: La Chine une puissance incertaine? La Revue Nouvelle, 68(4), 26-28. https://lirias.kuleuven.be/1910305

China Statistics Press. (2005). China Foreign Economic Statistics Yearbook 2005. http://www.stats.gov.cn/tjsj/ndsj/2005/indexeh.htm

Christopher, W. (2020). To understand China's aggressive foreign policy, look at its domestic politics. Council on Foreign Relations. https://www.cfr.org/blog/understand-chinasaggressive-foreign-policy-look-its-domestic-politics

Deych, T. (2018). China in Africa: Neo-colonial power or "win-win" strategy? Outlines of global transformations. Politics, Economics, and Law, 11, 119-141. https://doi.org/ 10.23932/2542-0240-2018-11-5-119-141

Duarte, P. (2012). The road to El Dorado: China discovers Africa - Meridiano 47. Journal of Global

Studies, 13(131), http://periodicos.unb.br/index.php/MED/article/download/4545/4144\#page=23

Gill, B., \& Reilly, J. (2007). The tenuous hold of China Inc. in Africa. Washington Quarterly, 30(3), 37-52. https://doi.org/10.1162/wash.2007.30.3.37

Jerden, B. (2014). The assertive China narrative: Why it is wrong and how so many still bought into it. The Chinese Journal of International Politics, 7(1), 47-88. https://doi.org/10.1093/cjip/pot019 
Jisi, W. (2011). China's search for a grand strategy: A rising great power finds its way. Foreign Affairs, 90(2), 68-79. http://www.jstor.org/stable/25800458

Johnson, K. (2015). China's military blueprint: Bigger navy, bigger global role. Foreign Policy. https://foreignpolicy.com/2015/05/26/chinas-military-blueprint-bigger-navybigger-global-role/

Khan, A. M., Rahim, N., \& Yousufi, M. (2020). China factor in the Sudan crisis: A politicoeconomic perspective. Liberal Arts and Social Sciences International Journal (LASSIJ), 4(2), 320-330. https://doi.org/10.47264/idea.lassij/4.2.25

Khatoon, A., Rahim, N., \& Ali, B. (2018). A historical perspective of China's peaceful policies and its rise as world economic power. Liberal Arts and Social Sciences International Journal (LASSIJ), 2(1), 65-74. https://doi.org/10.47264/idea.lassij/2.1.8

Mahamat, A. (2006, January 13). Africa starting to rise in partnership with China. China Daily. http://www.china.org.cn/english/international/155053.htm

Meidan, M. (2006). China's Africa policy: Business now, politics later. Asian Perspective, 30(4), 69-93. http://www.jstor.org/stable/42704565

Ministry of Commerce, China. (2005). The economic and trade relations between China and African countries in 2004. China Business Yearbook 2005. China Business. http://www.yearbook.org.cn:80/english/yearbook_view/2005/2005contents.htm

Mohan, G., \& Power, M. (2008). New African choices? The politics of Chinese engagement. Review of African Political Economy,35(115), 23-42. https://doi.org/10.1080/03056240802011394

Mukhtar, M., Sherazi, T. Z., \& Ahmad, R. (2020). Chinese traditional governing approach: An analysis from ancient to Mao Zedong politics. Liberal Arts and Social Sciences International Journal (LASSIJ), 4(2), 441-452. https://doi.org/10.47264/idea.lassij/4.2.34

Niall, D. (2019). China foreign-policy actors in Africa. Springer. https://link.springer.com/chapter/10.1007/978-981-13-8813-2_6

Otele, O. M. (2020). Introduction - China-Africa relations: Interdisciplinary question and theoretical perspectives. The African Review, 47(2), 267-284. https://doi.org/10.1163/1821889X-12340019

Ottaway, M. (1978). Soviet Marxism and African socialism. The Journal of Modern African Studies, 16(3), 477-485. https://www.jstor.org/stable/160038

Osondu, A. (2013). Off and on: China's principle of non-interference in Africa. Mediterranean Journal of Social Sciences, 4(3), 225-225. https://doi.org/10.1163/1821889X12340019

Perlo-Freeman, S. (2014). Deciphering China's latest defence budget figures. Stockholm International Peace Research 43. http://www.sipri.org/media/newsletter/essay/perlo-freeman-mar-2013

Rahim, N., Mehmood, A., \& Bukhari, S. M. H. S. (2019). Political instability in Sudan after military coup: Implications for China's economic interests. Liberal Arts and Social Sciences International Journal (LASSIJ), $\quad 3(2), \quad$ 1-10. https://doi.org/10.47264/idea.lassij/3.2.1

Sandra, G. (2001). South-South transfer: A study of Sino-African exchanges. Routledge.

Sandra, G. (2001). South-South transfer: A study of Sino-African exchanges. PhD thesis submitted to the Department of Theory and Policy Studies, University of Toronto. https://www.nlc-bnc.ca/obj/s4/f2/dsk1/tape7/PQDD_0018/NQ41158.pdf

Shambaugh, D. L. (2014). China goes global: The partial power (Vol. 409). Oxford University. https://doi.org/10.1002/polq.12242 
Shinn, D.H., \& Eisenman, J. (2012). China and Africa: A century of engagement. University of Pennsylvania.

Sun, Y. (2013). BRICS and China's aspiration for the new international order. Brookings UpFront Blog, The Brookings Institution. http://www.brookings.edu/blogs/upfront/posts/2013/03/25-xi-jinping-china-brics-sun

Tania, G. (2019). To what extent has China's security policy evolved in sub-Saharan Africa? E-International Relations. https://www.e-ir.info/2019/12/26/to-what-extent-haschinas-security-policy-evolved-in-sub-saharan-africa/

Tarun, C. \& Ryan, H. (2019). Global China: Domestic politics and foreign policy. Brookings, Global China assessing China's growing role in the world. https://www.brookings.edu/research/global-china-domestic-politics-and-foreignpolicy/

Tjonneland, E. N. (2014). China and African politics - from non-interference to reluctant engagement? Paper presented at the International Conference China and Africa Media, Communications and Public Diplomacy at Beijing, 10 - 11 September 2014. https://www.cmi.no/file/2919-.pdf

Weinstein, W., \& Henriksen, T. H. (1980). Soviet and Chinese aid to African nations. Praeger. Xinhua News Agency. (2012). China's Loan to Ghana to Benefit Ghanaians: Minister. http://english.peopledaily.com.cn/90883/7779 012.html

Zhao, S. (2012). Shaping the regional context of China's rise: How the Obama administration brought back hedge in its engagement with China. Journal of Contemporary China, 21(75), 369-389. https://doi.org/10.1080/10670564.2011.647428 